\title{
Factors Affecting the Lime Requirement in Acidic Inceptisols of Jharkhand
}

\author{
Ritabrata Bhowmick ${ }^{1 *}$, Jajati Mandal ${ }^{2}$ and Nintu Mandal ${ }^{2}$
}

${ }^{1}$ Dept. of Chemistry, Techno India, Batanagar, Maheshtala, Kolkata, West Bengal (700 141), India

${ }^{2}$ Dept. of Soil Science and Agricultural Chemistry, Bihar Agricultural University, Sabour, Bhagalpur, Bihar (813 210), India

Article History

Manuscript No. AR1653

Received in $10^{\text {th }}$ August, 2016

Received in revised form $28^{\text {th }}$ September, 2016

Accepted in final form $6^{\text {th }}$ October, 2016

\section{Correspondence to}

*E-mail: ritabratabhowmick@gmail.com

\section{Keywords}

Acid soils, lime requirement, $\mathrm{pH}$, clay, lime potential, correlation

\begin{abstract}
Perhaps the most outstanding features of the soil solution are its reaction i.e. whether it is acidic or alkaline or neutral. Acid soils are problematic soils because of the fact that soil acidity is a serious threat to profitable crop production and lime is essential for correlation of acidity as well as of toxic and infertile condition likely to be prevalent in the acid soils. A considerable amount of work is necessary to define the optimum $\mathrm{pH}$ range for the principle crops and rotation systems practiced in the state, to measure the yield responses to be expected for the more important soil types and to determine the longevity of the lime response. Adsorbed cations, Hydrogen $\left(\mathrm{H}^{+}\right)$ and Aluminium $\left(\mathrm{Al}^{3+}\right)$ are largely responsible for soil acidity. The present study was conducted in the Department of Chemistry, Techno India, Batanagar in the year 2015 to determine the Lime Requirement (LR) of acid soils collected from three soil series of Jamtara district of Jharkhand viz., Kunjabana (I), Bhandarbera and Kunjabana (II). In order to determine the LR, the soils were incubated with different doses of lime (Calcium Carbonate) and the result obtained was in the following order: Kunjabana I $>$ Kunjabana II $>$ Bhandarbera. The lime requirement showed significant correlation with $\mathrm{pH}\left(\mathrm{H}_{2} \mathrm{O}\right)(r=-0.69), \mathrm{pH}(\mathrm{KCl})(r=-0.59)$, clay content $(r=-0.53)$, organic matter $(r=0.65)$, the product of the increase in $\mathrm{pH}$ value due to liming and organic matter $(r=0.71), \mathrm{CEC}(r=0.63), \log \mathrm{CEC}(r=0.65), \mathrm{AlKCl}(r=0.71), \mathrm{FeNH}_{4} \mathrm{OAc}(r=0.65)$, $\mathrm{AlNH}_{4} \mathrm{OAc}(r=0.59)$, total potential acidity $(r=0.52)$ and lime potential $(r=-0.84)$.
\end{abstract}

\section{Introduction}

Acid soils are problematic soils because of the fact that soil acidity is a serious threat to profitable crop production and lime is essential for correlation of acidity as well as of toxic and infertile condition likely to be prevalent in the acid soils. Out of $328 \mathrm{mt}$ of geographical area of India, nearly $145 \mathrm{mha}$ is cultivated and a rough estimate indicate that $48 \mathrm{mha}$ of soil is acidic out of which 25 mha of soil shows $\mathrm{pH}<5.5$ and are critically degraded acid lands with low productivity (Sanyal and Bhattacharya, 2012). In all those tracts of the country where rainfall and temperature are high, acid soils are predominantly found. The North-eastern region has the largest stretches of acid soils, followed by neighbouring states of West Bengal, Bihar, Jharkhand and Orissa. Lime for use in Jharkhand must be hauled over long distances so that it is likely to be relatively expensive. It is imperative, therefore, that it be used as efficiently as possible. A considerable amount of work is necessary to define the optimum $\mathrm{pH}$ range for the principle crops and rotation systems practiced in the state, to measure the yield responses to be expected for the more important soil types and to determine the longevity of the lime response (Dolui and Banerjee, 2002). On strongly acid soils the majority of the crops suffer a significant reduction in yield mainly due to deficiency of $\mathrm{Ca}, \mathrm{K}, \mathrm{Mg}$ and toxicity of $\mathrm{Al}$ and $\mathrm{Fe}$. On the other hand deficiency of N, P and S due to very slow organic matter decomposition, as acid soils are not good habitat for micro-organism also acts as an additional factor for yield reduction (Tisdale and Nelson, 2009). Therefore liming is a very important measure for reclamation of acid soils. Prior to addition of lime it is important to know the amount which is to be added to an acid soil to raise the $\mathrm{pH}$ to a desired level, generally in a neutral range. Keeping this in view a modest initiative has been taken to determine the lime requirement of acid soils collected from three soil series of Jamtara district of Jharkhand.

\section{Materials and Methods}

Three red soil profiles of Kunjabana (I), Bhandarbera and Kunjabana (II) series in Jamtara district of lower Ganga 
basin catchment of Jharkhand, India were collected during the month of January 2015 based on the information of soil survey conducted by All India Soil and Land Use Survey, GOI, Kolkata. The profiles were examined and soils were collected horizon wise. According to the taxonomical classification Kunjabana (I) series belongs to fine mixed hyperthermic typic Ustochrepts, Bhandarbera series belongs to fine loamy mixed hyperthermic typic Ustochrepts, Kunjaban (II) series belongs to fine mixed hyperthermic typic Ustochrepts. The samples were air dried, grounded and passed through $2 \mathrm{~mm}$ sieve and kept in sampling bottles for subsequent analysis. The physicochemical properties of soils were determined as the methods ${ }^{-1}$ depicted in Table 1.

In order to obtain the lime requirement values, soil samples were thoroughly mixed with varying quantities of analytical reagent $\mathrm{CaCO}_{3}$. A known weight (12.5 g) of soil was taken in each beaker with varying quantities of lime ranging from $5 \mathrm{mg}, 10 \mathrm{mg}, 20 \mathrm{mg}, 30 \mathrm{mg}, 40 \mathrm{mg}, 60 \mathrm{mg}$ and $80 \mathrm{mg}$. These correspond to $0.8,1.6,3.2,4.8,6.4,9.6$ and $12.8 \mathrm{me} \mathrm{kg}^{-1}$ of

Table 1: Determination of physico-chemical properties of soil samples

\begin{tabular}{|c|c|c|}
\hline Parameters & Method & References \\
\hline Texture & $\begin{array}{l}\text { International pipette } \\
\text { method }\end{array}$ & Piper, 1996 \\
\hline $\begin{array}{l}\text { Specific } \\
\text { conductance }\end{array}$ & soil:water ratio 1:5 & Jackson, 1958 \\
\hline $\mathrm{pH}$ & $\begin{array}{l}\text { Soil:water ratio } 1: 2.5 \\
\text { Soil: } 1(\mathrm{M}) \mathrm{KCl} \text { ratio } \\
1: 2.5\end{array}$ & Jackson, 1958 \\
\hline $\mathrm{SOC}$ & $\begin{array}{l}\text { Modified wet } \\
\text { oxidation method }\end{array}$ & $\begin{array}{l}\text { Walkley and Black, } \\
1934\end{array}$ \\
\hline $\mathrm{CEC}$ & $1(\mathrm{~N}) \mathrm{Ba}(\mathrm{OAc})_{2}$ & $\begin{array}{l}\text { Harda and Inko, } \\
1980\end{array}$ \\
\hline $\begin{array}{l}\text { Extractable } \\
\text { Fe and } \mathrm{Al}\end{array}$ & $\begin{array}{l}\text { Potassium chloride } \\
\text { extraction } \\
\text { Ammonium acetate } \\
\text { extraction }\end{array}$ & $\begin{array}{l}\text { Black, 1965; } \\
\text { Olsen and Carlson, } \\
\text { 1950; McLean et } \\
\text { al., } 1959\end{array}$ \\
\hline $\begin{array}{l}\text { Total ex- } \\
\text { changeable } \\
\text { acidity }\end{array}$ & $\begin{array}{l}\text { Extracting with } 1(\mathrm{~N}) \\
\mathrm{KCl} \text { and titrating with } \\
\text { standard } \mathrm{NaOH}\end{array}$ & Yuan, 1959 \\
\hline $\begin{array}{l}\text { Total poten- } \\
\text { tial acidity }\end{array}$ & $\begin{array}{l}\mathrm{BaCl}_{2} \text {-triethanolamine } \\
\text { method }\end{array}$ & Peech et al., 1962 \\
\hline $\begin{array}{l}\mathrm{pH} \\
\text { dependent } \\
\text { acidity }\end{array}$ & $\begin{array}{l}\text { Total potential } \\
\text { acidity-total } \\
\text { exchangable acidity }\end{array}$ & \\
\hline $\begin{array}{l}\text { Lime } \\
\text { potential }\end{array}$ & $\begin{array}{l}0.01(\mathrm{M}) \mathrm{CaCl}_{2} \\
\text { solution method }\end{array}$ & $\begin{array}{l}\text { Schofield and } \\
\text { Taylor, } 1955\end{array}$ \\
\hline
\end{tabular}

$\mathrm{Ca}^{2+}$. The mixture was then made homogeneous and the treated soils were equilibrated at field capacity and were incubated for 30 days at $25^{\circ} \mathrm{C}$. After 30 days the soil was air dried, ground and different types of $\mathrm{pH}$ were determined by glass electrode in soil:water ratio (1:2.5). From $\mathrm{pH}$ versus $\mathrm{CaCO}_{3}$ added curve the amount of lime needed to attain $\mathrm{pH} 6.5$ was calculated.

\section{Results and Discussion}

The physicochemical characteristics of the collected soil samples are reported in Table 2. From the Table it is apparent that all soils are extremely acidic to moderately acidic in reaction. On the basis of the mean $\mathrm{pH}$ (water) and $\mathrm{pH}(1 \mathrm{MKCl})$ values the soil series are arranged in order as Kunjabana I (5.3 and 4.8) $>$ Bhandarbera (5.3 and 4.7) $>$ Kunjabana II (5.1 and 4.7). The reverse order is observed in case of organic carbon content. This is obvious because organic carbon has inverse relation with soil $\mathrm{pH}$. The specific conductivity is low in all cases. Hence all the soils are free from soluble salts. Particle size distributions are studied to determine the degree of clay translocation in the profiles. Texturally the soils vary from sandy clay loam to clay. The Cation Exchange Capacity (CEC) of soils are analyzed and the order studied is Kunjabana II $>$ Kunjabana I $>$ Bhandarbera. The active constituent of the soil is clay and its surface charge give rise to CEC. From the Table 2 it is clear that clay and CEC has direct relationship. The Exchangeable Acidity (EA) includes the exchangeable $\mathrm{H}^{+}$ and $\mathrm{Al}^{3+}$ held at the permanent charge sites of the soil exchange complex viz., electro statically bonded (EB)- $\mathrm{H}^{+}$and (EB)- $\mathrm{Al}^{3+}$ acidities. The EA of all the soils were low ranging from 0.7 to 4.6, 1.2 to 3.9 and 1.6 to 3.7 with mean values of $1.8,2.4$ and

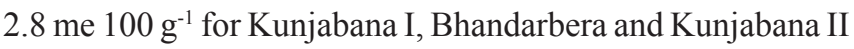
series, respectively (Table 3). Relatively lower exchangeable acidity has also been reported by Kumar et al. (1995) in the acidic soils of Manipur, Misra and Saithantuaanga (2000) in the acidic soils of Mizoram and Dolui and Bhattacharjee (2003) in the acidic soils of Assam. Acidity owing to variable charge ( $\mathrm{pH}$-dependent) (PDA) as measured by difference between total potential and Exchangeable Acidity (EA) ranged from 0.1 to 4.1 me $100 \mathrm{~g}^{-1}$ with a mean of 2.3 me $100 \mathrm{~g}^{-1}$. The results (Table 2) revealed that the mean values of PDA of the three soil series are in the order: Kunjabana I $(2.5 \mathrm{me}$ $\left.100 \mathrm{~g}^{-1}\right)=$ Kunjabana II (2.5 me $\left.100 \mathrm{~g}^{-1}\right)>$ Bhandarbera (1.8 me $\left.100 \mathrm{~g}^{-1}\right)$ which followed the decreasing trend of total potential acidity. On the other hand, Total Potential Acidity (TPA) showed a variation of 3.6 to $6.6 \mathrm{me} 100 \mathrm{~g}^{-1}$ with an average

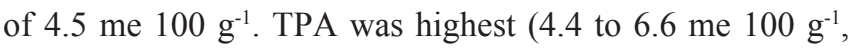
mean 5.3 me $100 \mathrm{~g}^{-1}$ ) in Kunjabana II series followed by the Kunjabana I series intermediate (3.7 to 5.1 me $100 \mathrm{~g}^{-1}$, mean

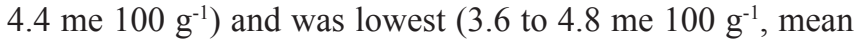




\begin{tabular}{|c|c|c|c|c|c|c|c|c|c|}
\hline \multirow[b]{2}{*}{ Depth (m) } & \multicolumn{2}{|c|}{$\mathrm{pH}$} & \multirow{2}{*}{$\begin{array}{c}\text { Specific } \\
\text { conductance } \\
\left(\mathrm{dS} \mathrm{m}^{-1}\right)\end{array}$} & \multicolumn{3}{|c|}{ Particle size distribution $\left(\mathrm{g} \mathrm{kg}^{-1}\right)$} & \multirow[t]{2}{*}{ Texture } & \multirow{2}{*}{$\begin{array}{c}\mathrm{SOC} \\
\left(\mathrm{g} \mathrm{kg}^{-1}\right)\end{array}$} & \multirow{2}{*}{$\begin{array}{c}\text { CEC (me } \\
\left.100 \mathrm{~g}^{-1}\right)\end{array}$} \\
\hline & $\mathrm{H}_{2} \mathrm{O}$ & $\begin{array}{l}1(\mathrm{M}) \\
\mathrm{KCl}\end{array}$ & & Sand & Silt & Clay & & & \\
\hline \multicolumn{10}{|c|}{ Pedon-A: Kunjabana I series } \\
\hline $0.00-0.12$ & 4.4 & 4.0 & 0.06 & 621 & 48 & 331 & SCL & 2.69 & 11.70 \\
\hline $0.12-0.31$ & 5.0 & 4.6 & 0.05 & 519 & 77 & 404 & $\mathrm{SC}$ & 1.70 & 11.70 \\
\hline $0.31-0.61$ & 5.3 & 4.7 & 0.05 & 359 & 465 & 176 & $\mathrm{~L}$ & 1.55 & 7.02 \\
\hline $0.61-0.91$ & 5.5 & 5.2 & 0.05 & 343 & 132 & 525 & $\mathrm{C}$ & 1.13 & 14.04 \\
\hline $0.91-1.13$ & 5.6 & 5.0 & 0.04 & 437 & 7 & 556 & $\mathrm{C}$ & 0.71 & 9.36 \\
\hline $1.13-1.38+$ & 5.7 & 5.4 & 0.04 & 424 & 232 & 344 & $\mathrm{CL}$ & 0.57 & 9.36 \\
\hline Mean & 5.3 & 4.8 & 0.05 & 450 & 160 & 390 & $\mathrm{CL}$ & 1.39 & 10.53 \\
\hline \multicolumn{10}{|c|}{ Pedon-B: Bhandanbera series } \\
\hline $0.00-0.13$ & 4.5 & 4.3 & 0.09 & 698 & 7 & 295 & $\mathrm{SCL}$ & 2.71 & 7.02 \\
\hline $0.13-0.27$ & 5.1 & 4.5 & 0.07 & 512 & 36 & 452 & $\mathrm{SC}$ & 1.97 & 7.02 \\
\hline $0.27-0.46$ & 5.4 & 4.7 & 0.07 & 553 & 93 & 354 & $\mathrm{SC}$ & 0.99 & 4.68 \\
\hline $0.46-0.77$ & 5.7 & 5.0 & 0.07 & 390 & 496 & 114 & $\mathrm{~L}$ & 0.71 & 7.02 \\
\hline $0.77-1.02+$ & 5.9 & 5.1 & 0.07 & 530 & 176 & 294 & SCL & 0.71 & 4.68 \\
\hline Mean & 5.3 & 4.7 & 0.07 & 536 & 162 & 302 & SCL & 1.42 & 6.08 \\
\hline \multicolumn{10}{|c|}{ Pedon-C: Kunjabana II series } \\
\hline $0.00-0.11$ & 4.6 & 4.4 & 0.07 & 457 & 102 & 441 & $\mathrm{C}$ & 1.98 & 21.06 \\
\hline $0.11-0.33$ & 5.5 & 4.4 & 0.07 & 543 & 172 & 285 & SCL & 2.54 & 16.38 \\
\hline $0.33-0.65$ & 5.0 & 4.8 & 0.06 & 422 & 100 & 478 & $\mathrm{C}$ & 1.98 & 14.04 \\
\hline $0.65-0.83+$ & 5.2 & 5.0 & 0.07 & 478 & 127 & 395 & $\mathrm{SC}$ & 1.27 & 11.70 \\
\hline Mean & 5.1 & 4.7 & 0.07 & 475 & 126 & 399 & $\mathrm{SC}$ & 1.94 & 15.80 \\
\hline
\end{tabular}

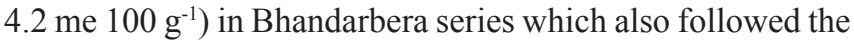
decreasing trend of $\mathrm{KCl}$ extractable $\mathrm{Al}, \mathrm{pH}$ dependent acidity, clay and cation exchange acidity.

Lime potential ranged from 2.7 to 4.0 with an average of 3.4. Lime potential increased with depth in all the soil series except the second horizon of Kunjaban II series. The lime potential followed the sequence: Kunjabana I (3.5)>Bhandarbera (3.4)>Kunjabana II (3.3). The graphical representation (Figure 1, 2 and 3) clearly reveals the Lime Requirement (LR) of the different horizons of the three pedons. The LR of the soil by $\mathrm{CaCO}_{3}$ incubation method revealed that the lime requirement varied from 0.8 to 3.2 me $100 \mathrm{~g}^{-1}$ with an average of $2.0 \mathrm{me}$ $100 \mathrm{~g}^{-1}$ in Kunjabana I series, 0.4 to 2.8 me $100 \mathrm{~g}^{-1}$ (mean 1.2 me $100 \mathrm{~g}^{-1}$ ) in Bhandarbera series and 0.5 to 3.2 me $100 \mathrm{~g}^{-1}$ (mean 1.9 me $100 \mathrm{~g}^{-1}$ ) in Kunjabana II series. Variation in lime requirement within the soil series is due to variability in the physical and chemical properties of the soils. On the basis of mean lime requirement value by incubation method, the soil series are arranged as Kunjabana I $>$ Kunjabana II $>$ Bhandarbera. Correlation between soil properties and LR is depicted in Table 3. Soil $\mathrm{pH}$ is one of the major factors to indicate the amount of base required to neutralize the acidity, the LR showed negative relationship with $\mathrm{pH}\left(\mathrm{H}_{2} \mathrm{O}\right)$ and $\mathrm{pH}$ $(\mathrm{KCl})$ which were statistically significant. Similar results have been reported by Kisinyo et al. (2014). A negative correlation being statistically significant of $r=-0.53$ was also recorded between LR and clay content. This is due to, since clay being a colloidal constituent of the soil and hence it is contributing a significant share to the buffering capacity and LR of the soils. SOC and LR showed a positive correlation $(r=0.65)$ which was statistically significant. This is because organic matter substantially contributes to the cation exchange capacity of the soil and its correlation with LR is therefore expected. Kisinyo et al. (2014) illustrated relation between LR and the product of increase in $\mathrm{pH}$ value due to liming and the organic matter content, i.e. ( $\mathrm{pH}$ at which LR value was calculated-initial $\mathrm{pH}) \times$ organic matter. Such correlation was also attempted in the present case. High correlation was obtained between LR and the above product with $r=0.71$ which was also statistically significant. The result is important since LR of the acid soils 


\begin{tabular}{|c|c|c|c|c|c|c|c|c|c|}
\hline \multirow[t]{2}{*}{ Depth (m) } & \multicolumn{2}{|c|}{$1(\mathrm{M}) \mathrm{KCl}$} & \multicolumn{2}{|c|}{ 1(M) $\mathrm{NH}_{4} \mathrm{OAc}$} & \multirow{2}{*}{$\begin{array}{c}\text { Exchange- } \\
\text { able } \\
\text { acidity }\end{array}$} & \multirow{2}{*}{$\begin{array}{c}\mathrm{pH} \\
\text { dependent } \\
\text { acidity }\end{array}$} & \multirow{2}{*}{$\begin{array}{c}\text { Total } \\
\text { potential } \\
\text { acidity }\end{array}$} & \multirow{2}{*}{$\begin{array}{c}\text { Lime } \\
\text { potential }\end{array}$} & \multirow{2}{*}{$\begin{array}{c}\text { Lime } \\
\text { requirement } \\
\left(\mathrm{me} 100 \mathrm{~g}^{-1}\right)\end{array}$} \\
\hline & $\begin{array}{c}\mathrm{Fe} \\
\left(\mathrm{mg} \mathrm{kg}^{-1}\right)\end{array}$ & $\begin{array}{c}\mathrm{Al} \\
\left(\mathrm{mg} \mathrm{kg}^{-1}\right)\end{array}$ & $\begin{array}{c}\mathrm{Fe} \\
\left(\mathrm{mg} \mathrm{kg}^{-1}\right)\end{array}$ & $\begin{array}{c}\mathrm{Al} \\
\left(\mathrm{mg} \mathrm{kg}^{-1}\right)\end{array}$ & & & & & \\
\hline \multicolumn{10}{|c|}{ Pedon-A: Kunjabana I series } \\
\hline $0.00-0.12$ & 1.7 & 53.0 & 8.5 & 56.0 & 4.6 & 0.1 & 4.7 & 2.8 & 3.2 \\
\hline $0.12-0.31$ & 0.8 & 18.0 & 3.4 & 44.8 & 2.3 & 2.8 & 5.1 & 3.2 & 2.4 \\
\hline $0.31-0.61$ & 1.2 & 18.0 & 2.2 & 34.0 & 0.7 & 4.1 & 4.8 & 3.6 & 0.8 \\
\hline $0.61-0.91$ & 1.2 & 3.0 & 2.2 & 29.2 & 0.7 & 3.0 & 3.7 & 3.7 & 2.6 \\
\hline $0.91-1.13$ & 2.9 & 11.5 & 2.2 & 28.0 & 1.6 & 2.3 & 3.9 & 3.8 & 1.8 \\
\hline $1.13-1.38+$ & 0.8 & 6.0 & 2.2 & 19.6 & 1.0 & 2.9 & 3.9 & 3.9 & 1.3 \\
\hline Mean & 1.4 & 18.3 & 3.5 & 35.3 & 1.8 & 2.5 & 4.4 & 3.5 & 2.0 \\
\hline \multicolumn{10}{|c|}{ Pedon-B: Bhandanbera series } \\
\hline $0.00-0.13$ & 0.8 & 24.5 & 8.5 & 50.0 & 3.9 & 0.5 & 4.4 & 2.7 & 2.8 \\
\hline $0.13-0.27$ & 1.2 & 11.5 & 2.2 & 47.6 & 2.0 & 2.6 & 4.6 & 3.1 & 1.3 \\
\hline $0.27-0.46$ & 2.5 & 8.5 & 2.2 & 34.0 & 2.8 & 2.0 & 4.8 & 3.5 & 0.8 \\
\hline $0.46-0.77$ & 2.9 & 4.3 & 1.1 & 28.0 & 2.2 & 1.4 & 3.6 & 3.9 & 0.6 \\
\hline $0.77-1.02+$ & 1.2 & 3.0 & 1.1 & 18.0 & 1.2 & 2.5 & 3.7 & 4.0 & 0.4 \\
\hline Mean & 1.7 & 10.4 & 3.0 & 35.5 & 2.4 & 1.8 & 4.2 & 3.4 & 1.2 \\
\hline \multicolumn{10}{|c|}{ Pedon-C: Kunjabana II series } \\
\hline $0.00-0.11$ & 1.7 & 34.5 & 3.4 & 54.4 & 3.7 & 3.1 & 6.6 & 3.1 & 3.2 \\
\hline $0.11-0.33$ & 0.8 & 45.5 & 3.4 & 63.2 & 3.5 & 0.9 & 4.4 & 3.0 & 2.2 \\
\hline $0.33-0.65$ & 1.7 & 11.5 & 1.1 & 44.8 & 1.6 & 3.6 & 5.2 & 3.5 & 1.5 \\
\hline $0.65-0.83+$ & 1.7 & 2.3 & 1.1 & 31.6 & 2.3 & 2.5 & 4.8 & 3.7 & 0.5 \\
\hline Mean & 1.5 & 23.5 & 2.3 & 48.5 & 2.8 & 2.5 & 5.3 & 3.3 & 1.9 \\
\hline
\end{tabular}

can be evaluated from the $\mathrm{pH}$ and organic matter content which are routinely estimated in many soil testing laboratories. The positive correlation with $\mathrm{pH}$ is mainly due to buffering capacity of the soil as it behaves like a weak acid that will buffer $\mathrm{pH}$ change. Organic matter on the other hand are subjected to decomposition which results in the production of $\mathrm{H}^{+}$ions which also contributes towards buffering and hence the correlation as reported by Nduwumuremyi et al. (2014).

Cation Exchange Capacity (CEC) also showed a significant positive correlation with LR $(r=0.63)$. CEC indicates the total negative charge of the colloid and in acid soil may be related to the reserve acidity and to the buffering capacity of the soil. Potential acidity represents the $\mathrm{H}^{+}$and $\mathrm{Al}^{3+}$ on the CEC. Soil $\mathrm{pH}$ measurements are excellent indicators of soil acidity, but do not measure potential acidity. Quantifying potential acidity requires titrating the soil with a base, which can be used to determine the LR needed to increase the $\mathrm{pH}$ to a desired level. Thus LR of a soil is related not only to soil $\mathrm{pH}$ but also to CEC. Similar results were also reported by Xu et al. (2012). The correlation with LR could thus be explained Table 4. Both $\mathrm{KCl}$ and $\mathrm{NH}_{4} \mathrm{OAc}$ extractable $\mathrm{Fe}$ and $\mathrm{Al}$ showed a significant
Table 4: Correlation coefficients between lime requirement and different soil parameters

\begin{tabular}{|c|c|}
\hline Soil factors & Value of $r$ \\
\hline pH (soil:water) & $-0.69^{* *}$ \\
\hline pH (soil:KCl) & $-0.59^{* *}$ \\
\hline Clay $\mathrm{g} \mathrm{kg}^{-1}$ & $-0.53^{* *}$ \\
\hline $\mathrm{SOC} \mathrm{g} \mathrm{kg}^{-1}$ & $0.65^{* *}$ \\
\hline$(6.5$-original $\mathrm{pH}) \times \mathrm{SOC}$ & $0.71^{* *}$ \\
\hline CEC & $0.63^{* *}$ \\
\hline $\mathrm{FeKCl}$ & 0.20 \\
\hline $\mathrm{AlKCl}$ & $0.71^{* *}$ \\
\hline $\mathrm{FeNH}_{4} \mathrm{OAc}$ & $0.65^{* *}$ \\
\hline $\mathrm{AlNH}_{4} \mathrm{OAc}$ & $0.59^{* *}$ \\
\hline Total exchangeable acidity & 0.48 \\
\hline pH-dependent acidity & -0.34 \\
\hline Total potential acidity & $0.52^{* *}$ \\
\hline Lime potential & $-0.84^{* * *}$ \\
\hline
\end{tabular}

${ }^{* * *}$ : Significant at $p=0.001$ level if $\mathrm{r} \geq 0.74 ;{ }^{* *}$ : Significant at $p=0.01$ level if $\mathrm{r} \geq 0.62 ;^{*}$ : Significant at $p=0.05$ level if $\mathrm{r} \geq 0.50$ 


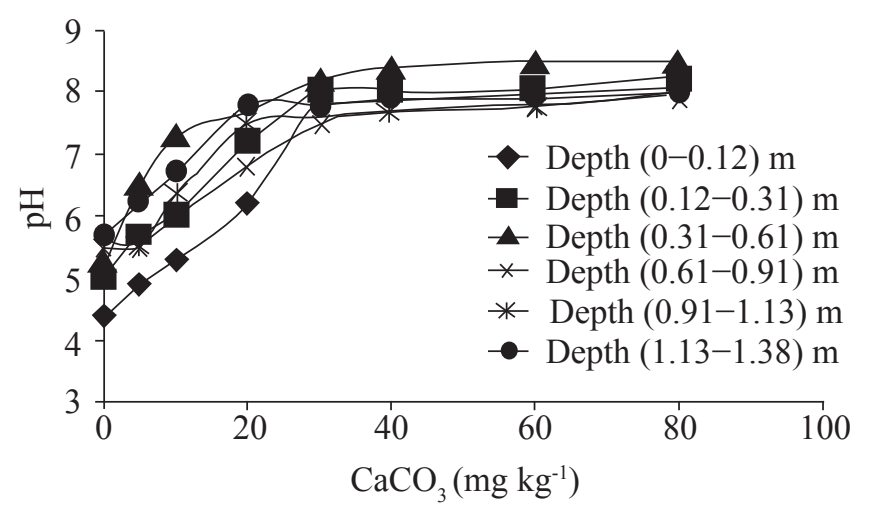

Figure 1: Kunjabana I

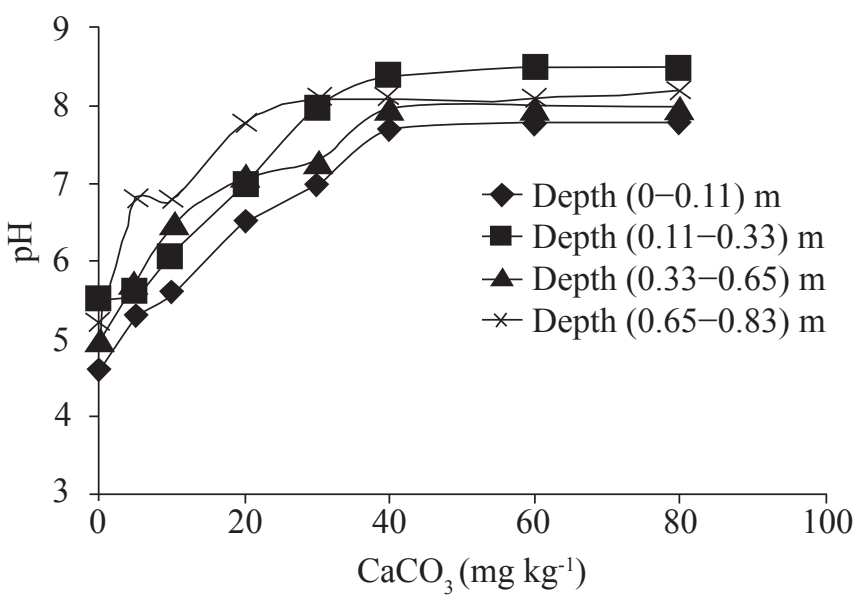

Figure 2: Bhanderbera

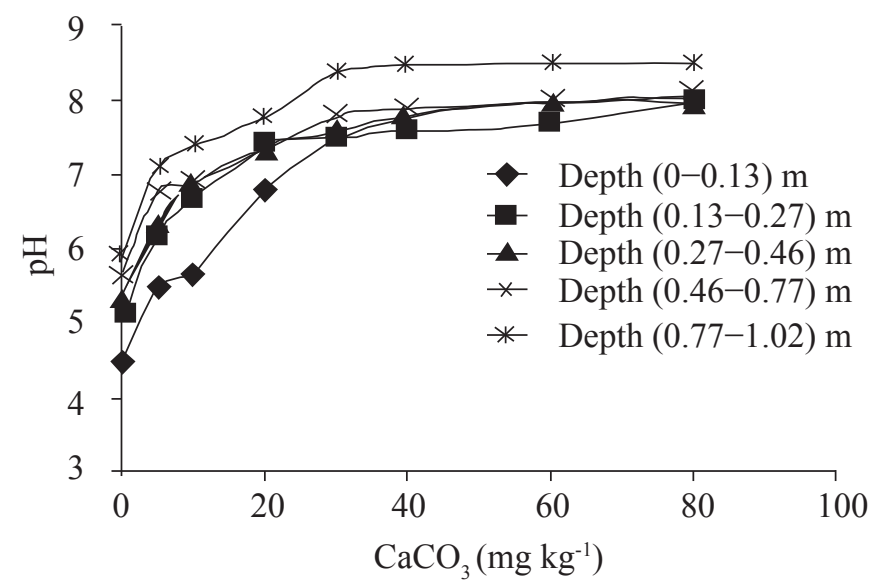

Figure 3: Kunjabana II

The graphical representation [Figure 1 (Kunjabana I), Figure 2 (Kunjabana II) and Figure 3 (Bhanderbera Series)] of Lime Requirement (LR) of the different horizons of the above mentioned three pedons

positive correlation with $\mathrm{LR}$ of the soils. If a base $\left(\mathrm{CaCO}_{3}\right)$ is added, $\mathrm{H}^{+}$will be neutralized first. With continued addition of base, $\mathrm{Al}^{3+}$ hydrolyzes, with the production of $\mathrm{H}^{+}$. In this way, $\mathrm{Al}^{3+}$ hydrolysis buffers the increase in solution $\mathrm{pH}$. Soil $\mathrm{pH}$ will not increase until sufficient base is added to decrease soluble
$\mathrm{Al}^{3+}$. Iron $(\mathrm{Fe})$ hydrolysis is similar to that of Al. Although the reaction of $\mathrm{Fe}^{3+}$ is more acidic than $\mathrm{Al}^{3+}$ hydrolysis the acidity is buffered by $\mathrm{Al}$ hydrolysis reaction. Thus, $\mathrm{Fe}^{3+}$ hydrolysis has little effect on soil $\mathrm{pH}$ until most of the soil $\mathrm{Al}$ has reacted. $\mathrm{Al}$ and Fe hydroxides occur as amorphous or crystalline colloids, coating the clay and other mineral surfaces. Total potential acidity also showed significant correlation with LR $(r=0.52)$. The correlation with total potential acidity indicates that the incubation of the soils with $\mathrm{CaCO}_{3}$ has the prospective to estimate the LR of these soils. The findings are in agreement with observations of Dolui and Banerjee (2002). The lime potential exhibited significant negative correlation with LR $(r=-0.84)$. This finding established the fact that lime potential being a characteristic property of the soil is not affected by addition of neutral salt whereas the $\mathrm{pH}$ undergoes change. The lime potential can be used to measure the degree of base saturation.

\section{Conclusion}

Lime requirement of three red soil profiles belonging followed the order: Kunjabana I $>$ Kunjabana II $>$ Bhandarbera. The lime requirement showed significant correlation with $\mathrm{pH}\left(\mathrm{H}_{2} \mathrm{O}\right)$ $(r=-0.69), \mathrm{pH}(\mathrm{KCl})(r=-0.59)$, clay content $(r=-0.53)$, organic matter $(r=0.65)$, the product of the increase in $\mathrm{pH}$ value due to liming and organic matter $(r=0.71), \mathrm{CEC}(r=0.63), \log \mathrm{CEC}$ $(r=0.65), \mathrm{AlKCl}(r=0.71), \mathrm{FeNH}_{4} \mathrm{OAc}(r=0.65), \mathrm{AlNH}_{4} \mathrm{OAc}$ $(r=0.59)$, total potential acidity $(r=0.52)$ and lime potential $(r=-0.84)$.

\section{References}

Black, C.A., 1965. Methods of Soil Analysis Part II. American Society of Agronomy Inc. Publishers, Madison, Wisconsin, USA.

Dolui, A.K., Banerjee, R., 2002. Forms of acidity in relation to lime requirement in Ultisols and Inceptisols of West Bengal. Journal of Research (Birsa Agricultural University) 14, 15-20.

Dolui, A.K., Bhattacharjee, S., 2003. Nature of soil acidity in relation to properties and lime requirement of some Inceptisols. Pedosphere 13, 181-188.

Dolui, A.K., Karmahapatra, S., 1996. Relationship between lime requirement and soil properties in some acid soils of Orissa and West Bengal, India. International Journal of Tropical Agriculture 14, 189-196.

Harda, Y., Inko, A.,1980. The measurement of CEC of composts for the estimation of the degree of maturity. Soil Science and Plant Nutrition 26, 127-134.

Jackson, M.L., 1958. Soil chemical analysis, Prentice Hall of India Private Limited, New Delhi.

Keeney, D.R., Corey, R.B., 1963. Factors affecting the lime requirements of Wisconsin soils. Soil Science Soceity of 
America Proceedings 27, 277-280.

Kisinyo, P.O., Othieno, C.O., Gudu, S.O., Okalebo, J.R., Opala, P.A., Maghanga, J.K., Ng'etich1, W.K., Agalo, J.J., Opile1, R.W., Kisinyo, J.A., Ogola, B.O., 2013. Phosphorus sorption and lime requirements of maize growing acid soils of Kenya. Sustainable Agriculture Research 2(2), 116-123.

Kumar, K., Rao, K.V.P., Singh, L.J., 1995. Forms of soil acidity in some inceptisols under different land use in Manipur. Journal of the Indian Society of Soil Science 43, 338-342.

Misra, U.K., Saithantuaang, H., 2000. Characterization of acid soils of Mizoram. Journal of the Indian Society of Soil Science 48, 437-446.

Nduwumuremyi, A., Habimana, S., Alexis, T., Mupenzi, J., 2014. Soil acidity analysis and estimation of lime requirement for rectifying soil acidity. International Invention Journal of Agricultural and Soil Science 2(2), 22-26.

Olsen, R.V., Carlson, C.W., 1950. Iron chlorosis of sorghums and trees as related to extractable soil iron and manganese. Soil Science Society America Proceedings 14, 109-112.

Peech, M., Cowan, R.L., Baker, J.H., 1962. A critical study of the $\mathrm{BaCl}_{2}$-trietanolamine and the $\mathrm{NH}_{4} \mathrm{OAc}$ methods for determining the exchangeable hydrogen content of soils. Soil Science Society America Proceedings 26, 37-40.
Piper, C.S., 1996. Soil and Plant analysis, Hans Publishers, Mumbai.

Sanyal, S.K., Bhattacharyya, K., 2012. Chemistry of acid soils of India-distribution, properties and management for sustainable. In: Sudhir, K. (Eds.), Special publication on acid soils of india-distribution, properties and management for sustainable crop production. The $8^{\text {th }}$ International symposium on plant-soil interactions at low pH, held on October 18-22, 2012, University of Agricultural Sciences, GKVK Campus, Bengaluru, India, 15-44.

Schofield, R.K., Taylor, A.W., 1955. The measurement of soil pH. Soil Science Society America Proceedings 19, 164-167.

Tisdale, S.L., Nelson, W.L., Baton, J.D., 2009. Soil Fertility and Fertilizers, Macmillan, New York.

Walkley, A., Black, J.A., 1934. Determination of organic carbon in soils. Soil Science 37, 27-38.

Xu, R.K., Zhao, A.Z., Yuan, J.H., Jiang, J., 2012. pH buffering capacity of acid soils from tropical and subtropical regions of China as influenced by incorporation of crop straw biochars. Journal of Soils and Sediments 12, 494-502.

Yuan, T.L., 1959. Determination of exchangeable hydrogen in soils by titration method. Soil Science 88, 164-167. 